\title{
Homenaje a Patricio Manns
}

Por Mirka Arriagada Vladillo'

El nacido en Nacimiento

El vivido en vivimiento

El que no camina con la muerte

$\mathrm{Y}$ anda como una cigarra

cigarreando en la cigarrería

El que tomó los libros prohibidos

de la cinta roja, más allá

El nieto cómplice

del abuelo que funda ciudades

El niño que guardó los animales

en la cordillera de Nahuelbuta

para protegerlos del puma

y le mostró sus pequeños puños fieros

y el puma supo quién era ese niño

El que sostendría ese mismo gesto

para esconder amigos, cuatreros, pendencieros,

santos, niños descalzos, muchachas rojas

Que iría al manicomio con su guitarra

a hacer que los locos tocaran la cordura

de la palabra lluvia y la palabra relámpago

El que con su honda certera

le dio en el cráneo al cuervo sádico

y lo lanzó desplumado al fondo del abismo

Untó con cianuro su cerbatana

arrojándole una carcajada musical a la hiena

1 Nace en Antofagasta en 1964. Poeta y Psiquiatra. Algunos de sus textos aparecen en compilaciones, tales como: Antología de las Literaturas emergentes (Lom Ediciones, 1999). Los cuatro puntos cardinales son tres: el sur y el norte (Editorial Arte y Cultura, Cuba 2008). Aurora de audiovisuales y registros documentales como: "Continuidad de la memoria" y "Nudos y desnudos". Ha publicado los libros de poesía Lamentaciones, Gemidos y Ayes (Editorial Las Dos Fridas, 1998), Autobiogeografía (Autoedición, libro-objeto 2002), Cuando el amor de echó a morir como un perro (Mago Editores, 2014). Pompei et autres poemes ( Ed Luchito Ocelote Francia 2020) Canciones de Alejandría (Buenos Aires Poetry 2021). Fundadora del Comando eXcultura. 
dejándola, pellejo al sol, disecada

El que sirvió en su mesa

el destino roñoso de los tiranos

se colgó el collar de huesos de sus amados muertos

airado y bravío, recorrió con ellos el mundo

así ataviado

Terco se los trajo en el equipaje del destierro

y dijo ¡Vuelvo! Jamás vencido

con un abecedario de rabia y ternura

Decidió ser el tábano en el anca del país dormido

hasta despertarnos

Juntemos mi rabia, dos rabias, millones de rabias

para volver a ser uno en la raíz del árbol

donde se libra el antiguo combate del bien y el mal

Ahora le cantan

las calandrias vivas, las palomas vivas, las gaviotas vivas

y por sobre todos los cantos, le canta la ruiseñora viva,

la canción atávica que junta el caudal de vivos y muertos

a la memoria de la unidad del pueblo

Y él canta

porque aprendió a dejar de amar su seguridad

y sabe quién es

y sabe quiénes somos

La humanidad es trigo

y cada espiga lucha por su libertad

La humanidad es árbol

y cada flecha disparada será el triunfo del bosque

El que nació en Nacimiento

El que vivió en vivimiento

El que arroja los rufianes al basural

para volver al agua limpia

del manantial del canto

y seguirá cigarreando

como la cigarra

en la cigarrería. 